\title{
Microwave Assisted Conversion of an Amino Acid into a Fluorescent Solution
}

\author{
Lena Charlyn Greiler, ${ }^{1}$ Hajo Haase ${ }^{2}$ and Boris Mahltig ${ }^{1, *}$ \\ ${ }^{1}$ Niederrhein University of Applied Sciences, Faculty of Textile and Clothing Technology, Webschulstr. 31, \\ 41065 Mönchengladbach, Germany \\ ${ }^{2}$ Technische Universität Berlin, Institut für Lebensmitteltechnologie und Lebensmittelchemie, Gustav-Meyer Allee 25, \\ 13355 Berlin, Germany \\ *Corresponding author: E-mail: boris.mahltig@hs-niederrhein.de
}

Received: 31-05-2018

\begin{abstract}
Microwave assisted synthesis is a well established method in organic and inorganic chemistry. It is also used in material science to realize novel carbon nanoparticles exhibiting fluorescence properties. The results presented here are related to a microwave driven solvothermal process used for the conversion of amino acid and 1,2-diaminoethane into fluorescent solutions. Arginine, lysine and glycine are used as amino acids. The process temperatures are set in the range of $80^{\circ}$ to $140^{\circ} \mathrm{C}$ and the maximum process pressure is 4.5 bar. The process duration is set from 5 to 30 minutes. The fluorescence effect is increased with increasing temperature. The prepared aqueous fluorescent solutions can be used as media to introduce fluorescence in textile substrates. The current study can be understood as a first proof-of-concept of a very simple microwave-assisted solvothermal synthesis of fluorescent compounds useful for the modification of different substrates.
\end{abstract}

Keywords: Microwave synthesis; solvothermal process; fluorescence; carbon nanoparticles

\section{Introduction}

Nanoparticles made from metals or semi-metals are well known and intensively investigated during the last decades. ${ }^{1-8}$ In comparison, the investigations of nanoparticles made from carbon started only recently. The fluorescence properties of carbon nanoparticles are discovered in 2004 during the investigation of carbon nanotubes. ${ }^{9}$ Carbon nanoparticles with diameters below $10 \mathrm{~nm}$ are named carbon quantum dots or more simply C-dots. ${ }^{10}$ These C-dots are counted together with the other carbon modification of the fullerene type to the zero-dimensional carbon nanomaterials. ${ }^{11,12}$ Various different applications are suggested for C-dots, as e.g. biosensing, photocatalytic or fluorescent materials. ${ }^{13}$ The combination of C-dots into mesoporous materials is reported to be an innovative and interactive platform for new functional applications. ${ }^{14}$

It is suggested that the fluorescence properties of carbon nanoparticles are caused by defects of the particle surface. ${ }^{12,15}$ An important influence on the fluorescence is caused by presence of amino groups onto the carbon particle surface. ${ }^{16}$ It is reported that the nitrogen content influences the intensity and duration of luminescence of car- bon nanoparticles. Especially the preparation of carbon nanoparticles starting from nitrogen containing educts is expected to lead to high fluorescence components. ${ }^{11}$ Conventional fluorescence dyes often have the disadvantage of low light stability. With this background, the development of new fluorescent carbon particles is of high interest, especially to realize long-term stable fluorescent components. ${ }^{17,18}$

The preparation of carbon nanoparticles can be achieved by several methods and especially the use of biomaterial precursors is prominently reported in literature. Carbon dots can be prepared e.g. by treatment of chicken egg substrate with a plasma beam or by hydrothermal treatment of tomato extract. ${ }^{12,19}$ Microwave assisted preparations are well known in organic chemistry and are also applied for the preparation of carbon dots. ${ }^{15,20}$ The use of microwave assisted devices is very well known in organic chemistry to prepare new compounds with higher yield and high purity. ${ }^{21-25}$ For the synthesis of inorganic materials, microwave assisted procedures are also developed. Platinum nanoparticles are prepared by using a microwave assisted solvothermal technique. ${ }^{26}$ Metal particles of copper, silver and gold are available from microwave assisted 
solvothermal processes. ${ }^{27,28}$ Compounds such as titanium dioxide or calcium hydroxyapatite can be obtained with microwave processes. ${ }^{28,29}$

A very simple experiment shows the formation of carbon dots by the treatment of yogurt in a household microwave oven at $800 \mathrm{~W}$ for $30 \mathrm{~min}$. The carbon dots obtained by this method are reported to have a size of $2 \mathrm{~nm}$ and a significant content of nitrogen and oxygen. ${ }^{30}$ Biomaterials like the mentioned chicken egg, tomatoes or yogurt are attractive examples to show how simple the preparation of carbon dots is. However, the reproducibility of such preparations is limited, because of the possible variation in material composition of substances from natural resources.

Other scientists report the preparation of carbon nanodots using the precursors citric acid and tetraoctylammonium ions or several types of carbohydrates treated in a domestic microwave. ${ }^{31,32}$ Further, carbon quantum dots can be prepared by microwave treatment of very simple organic molecules such as the amino acid arginine and ethylendiamine in water. ${ }^{15,33,34}$ This preparation has been reported to be done in a domestic microwave oven with $700 \mathrm{~W}$ and duration of $3 \mathrm{~min}$. As result of this procedure a brown solid is obtained, which has to be cleaned by centrifugation, dialysis and freeze drying. ${ }^{15}$

With this background, the aim of the present investigation is to support a synthesis of fluorescent carbon nanoparticles under defined and controlled microwave assisted conditions. To reach this aim, an aqueous solution of an amino acid is treated in a synthesis microwave originally developed for organic synthesis. This microwave device is a closed system, so the preparation can be carried out under solvothermal conditions, which is one main difference to a conventional domestic microwave. Also the process temperature and pressure can be controlled during the preparation. By this microwave assisted process it is possible to prepare stable and transparent solutions with fluorescence properties. The correlation between process parameters and the gained fluorescence properties is clearly determined.

To give an example for a first application of these fluorescent solutions in a first proof-of-concept study, they are applied in a simple padding process onto textile substrates made from cotton.

\section{Experimental Section}

\section{1. Preparation}

For the preparation, two types of chemicals are used: 1.2-diaminoethane (ethylenediamine) $\mathrm{C}_{2} \mathrm{H}_{8} \mathrm{~N}_{2}$ and L-arginine monohydrochloride (arginine $\mathrm{HCl}$ ) $\mathrm{C}_{6} \mathrm{H}_{14} \mathrm{~N}_{4} \mathrm{O}_{2}$ $\mathrm{HCl}$ both from Carl Roth $\mathrm{GmbH}$ (Karlsruhe, Germany). First, $21.4 \mathrm{~mL}$ ethylenediamine is mixed into $160 \mathrm{~mL}$ distilled water. Second, $67.4 \mathrm{~g} \mathrm{~L}$-arginine monohydrochloride is dissolved in this solution. After stirring for 5 minutes, a colorless clear solution results. This solution is treated in a microwave synthesis device (Discover LabMate, CEM $\mathrm{GmbH}$, Kamp-Lintfort, Germany). Detailed information concerning this device are available in the literature..$^{35,36}$

Each preparation is performed with heating power of $250 \mathrm{~W}$. The process temperatures are set in the range from $80^{\circ}$ to $140{ }^{\circ} \mathrm{C}$. The process vessel is a closed system, so the preparation is done under solvothermal conditions. Process pressures are determined by the chosen process temperatures. The relation of process pressure to process temperature is depicted in Figure 1.

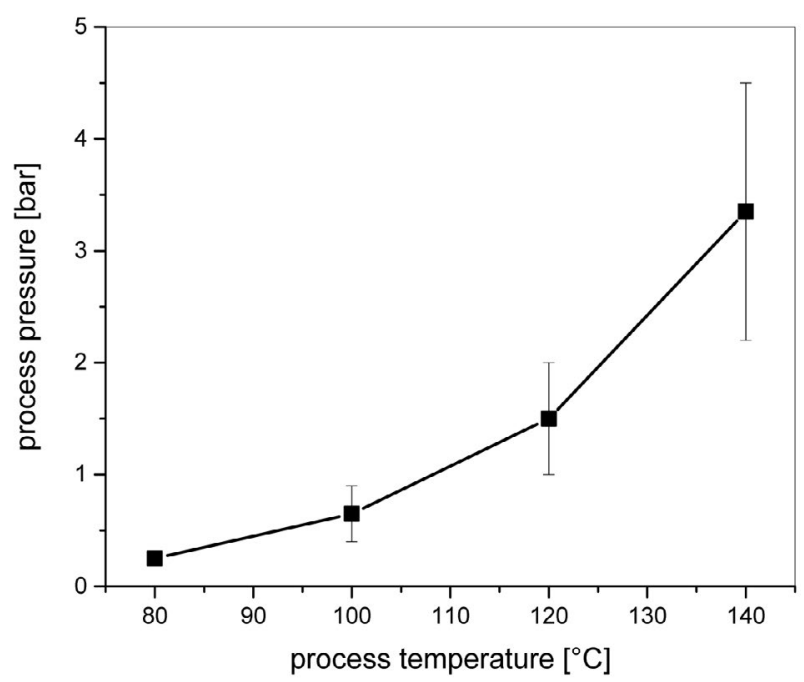

Figure 1. Process pressure as function of the set process temperature in the used solvothermal arrangement. The error bars indicate the range of process pressures observed during the whole process time of 5 minutes.

A typical temperature / pressure diagram as a function of time for a process temperature of $140^{\circ} \mathrm{C}$ is presented in Figure 2. After the set process temperature is reached,

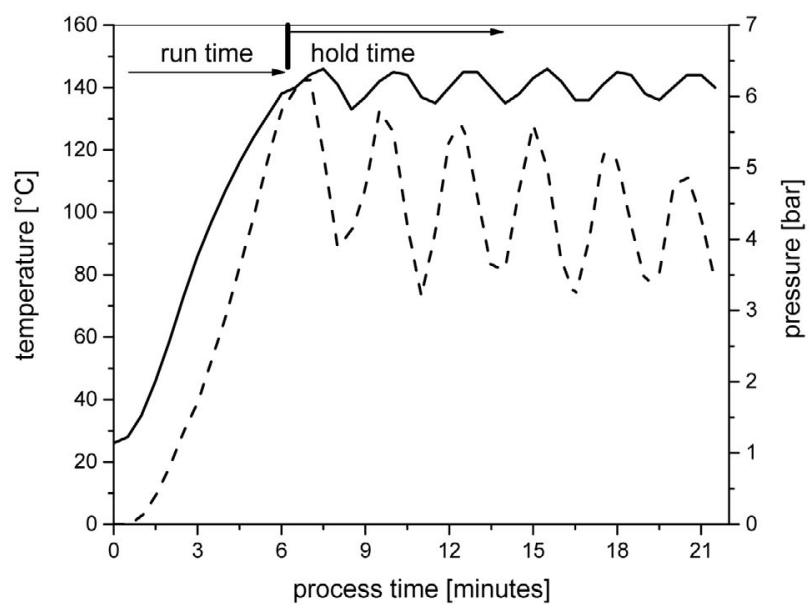

Figure 2. Process temperature and process pressure as a function of the process time. In this example the set temperature is $140^{\circ} \mathrm{C}$ and the process duration is $15 \mathrm{~min}$. This set temperature is reached after a run time of around $6 \mathrm{~min}$. 
the process duration starts. Process temperatures of higher than $140{ }^{\circ} \mathrm{C}$ are not tested, because of the pressure limits of the used device. For all process temperatures, the process duration is set to $5 \mathrm{~min}$. For the highest process temperature of $140{ }^{\circ} \mathrm{C}$, also longer process durations of 15 and 30 min are evaluated.

After microwave treatment the gained solutions appear clear and transparent. With treatment for 5 min duration, the solutions exhibit a light yellow color. Both samples prepared with heating to $140{ }^{\circ} \mathrm{C}$ and longer process duration, exhibit deeper yellow color and also a significant smell. The received solutions are subjected to dialysis against distilled water. For dialysis a tube with an average pore size of 2.5 to $3 \mathrm{~nm}$ is used (Nadir-Dialyseschlauch, Carl Roth GmbH, Karlsruhe, Germany). After dialysis solutions are colorless and their smell disappeared.

Further, the described microwave process is used to evaluate, if also other kind of amino acids beside L-arginine $\mathrm{HCl}$ are suitable precursors for the preparation of the fluorescent solutions. For this, the amino acids glycine $\mathrm{C}_{2} \mathrm{H}_{5} \mathrm{NO}_{2}$ and L-lysine monohydrochloride $\mathrm{C}_{6} \mathrm{H}_{14} \mathrm{~N}_{2} \mathrm{O}_{2}$ $\mathrm{HCl}$ are used as precursors. The amino acids are supplied by Carl Roth GmbH (Karlsruhe, Germany). For preparation of the starting solutions the amino acids are solved in mixtures of $21.4 \mathrm{~mL}$ ethylenediamine and $160 \mathrm{~mL}$ distilled water. $18 \mathrm{~g}$ glycine or $44 \mathrm{~g}$ L-lysine are used. For these preparations the process temperature is set to $140{ }^{\circ} \mathrm{C}$ and the process duration is set to 15 minutes. Also the use of L-histidine and L-tryptophan is evaluated. However, here unstable solutions with strong precipitation occur which are not further used in solvothermal microwave synthesis.

Solutions obtained after cleaning with dialysis are used for textile treatment. For this, cotton substrates with a size of $6 \mathrm{~cm} \mathrm{X} 3 \mathrm{~cm}$ and a weight per area of $388 \mathrm{~g} / \mathrm{m}^{2}$ are used. Cotton fabrics are chosen for the investigations due to the hydrophilic properties of cotton fibers. The up-take of the water based fluorescent solution is expected to be higher compared to hydrophobic synthetic fibers. Of course, also the application onto other textile fiber materials is possible. The textile treatment is done by dipping of the textile samples into the solutions. A subsequent drying is performed at room temperature or at $120^{\circ} \mathrm{C}$ in an oven.

\section{2. Analytics}

The first evaluation of the prepared solutions is done visually by illumination with a UV-lamp with a maximum intensity around 365 to $370 \mathrm{~nm}$ (Philips Lighting Holding B.V.). Further, the optical properties of the solutions are investigated using UV/Vis spectroscopy in transmission arrangement. For this, a UV-2600 spectrometer of Shimadzu is used.

Fluorescence properties are examined with a SPARK fluorescence well plate reader equipped with monochromators (Tecan Deutschland GmbH, Crailsheim, Germany). All measurements are performed by placing the sam- ples in 96-multiwell cell culture plates from TPP (Techno Plastic Products AG, Trasadingen, Switzerland), using 30 flashes per wavelength, an integration time of $40 \mu$ s and a lag time of $0 \mu \mathrm{s}$. For the investigation of liquids, $100 \mu \mathrm{L}$ per well are applied, measuring excitation spectra from 280 to $400 \mathrm{~nm}$ (in steps of $2 \mathrm{~nm}$ ) at an emission wavelength of $440 \mathrm{~nm}$. Emission spectra are recorded from 380 to 600 $\mathrm{nm}$ (4 $\mathrm{nm}$ steps) at an excitation wavelength of $360 \mathrm{~nm}$. In each case, measurements are performed as top reading with a Z-position of $15,500 \mu \mathrm{m}$, excitation and emission band widths of $5 \mathrm{~nm}$, and a manual gain of 100 . For the investigation of textile samples, $5 \mathrm{~mm}$ diameter disks are prepared by a conventional hole puncher, and analyzed in bottom reading mode with the $\mathrm{Z}$-position manually set to $31,000 \mu \mathrm{m}$ and a manual gain of 50 . Excitation spectra are obtained from 280 to $400 \mathrm{~nm}$ (steps of $10 \mathrm{~nm}$, excitation and emission band widths of $5 \mathrm{~nm}$ ) measuring the emission at $440 \mathrm{~nm}$. Emission spectra are recorded from 410 to $600 \mathrm{~nm}$ (10 nm steps, excitation and emission band widths of $10 \mathrm{~nm}$ ) at an excitation wavelength of $360 \mathrm{~nm}$.

\section{Results and Discussion}

\section{1. Properties of Prepared Solutions}

The prepared solutions are at first investigated simply by illumination with a UV-lamp emitting UV-A light. For all prepared samples, the fluorescence is obvious upon illumination with UV-A light (Figure 3). Even for the solution prepared with the lowest process temperature of $80^{\circ} \mathrm{C}$ and a short process duration of $5 \mathrm{~min}$, a fluorescence effect is observed. However, only the low fluorescence effect of the sample prepared at $80{ }^{\circ} \mathrm{C}$ is clearly indicated (Figure 3).

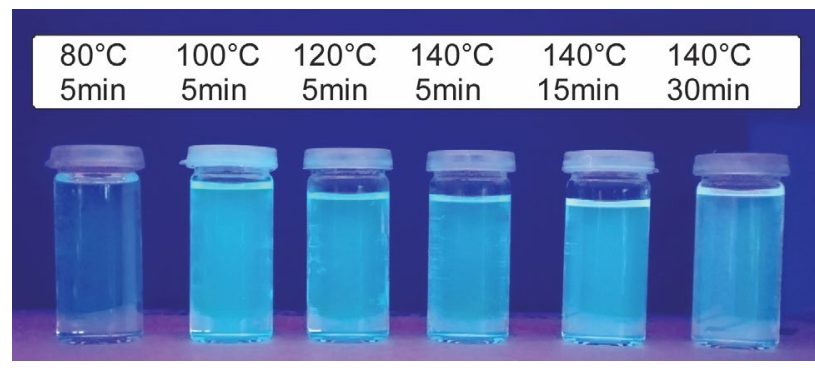

Figure 3. Solutions after preparation under illumination with a UV lamp. The process temperature and process duration is indicated for each solution.

The optical transmission of the prepared liquid samples is different for the UV-range from 230 to $400 \mathrm{~nm}$ (Figure 4), especially for the samples prepared with higher process temperature exhibiting a light yellow color, which is related to a lower optical transmission of these solutions for visible light in the range of 400 to $450 \mathrm{~nm}$. The sample prepared at $100{ }^{\circ} \mathrm{C}$ exhibits two minima in the transmis- 
sion spectrum at 290 and at $358 \mathrm{~nm}$. For the samples prepared at $120^{\circ}$ or $140{ }^{\circ} \mathrm{C}$, around $370 \mathrm{~nm}$ only a shoulder is detected in the transmission. However, the second minimum around $290 \mathrm{~nm}$ is more significant for these two samples. For UV-light below $240 \mathrm{~nm}$, all samples exhibit no transmission. The samples are cleaned by dialysis with a tube containing a pore size of 2.5 to $3 \mathrm{~nm}$. After the dial-
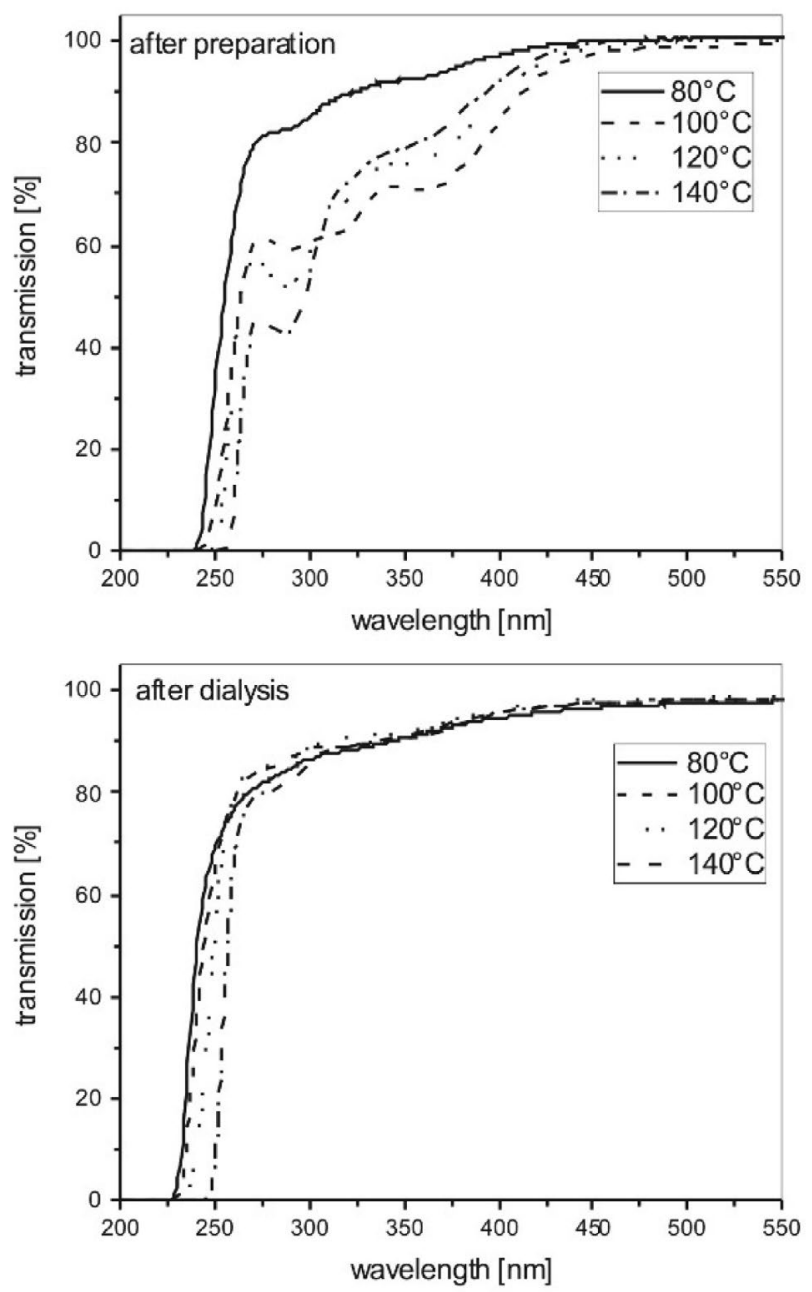

Figure 4. UV/Vis-transmission spectra of the prepared solution recorded directly after preparation (image above) and after treatment by dialysis (image below). Presented are spectra from solutions prepared at different process temperatures with a process duration of $5 \mathrm{~min}$.

ysis, the samples are non-smelling and the yellow color is disappeared, which is also confirmed by the optical transmission spectra shown in Figure 4.

The optical transmission spectra of the solutions prepared at $140{ }^{\circ} \mathrm{C}$ at different process durations are compared in Figure 5. Compared to the sample obtained after $5 \mathrm{~min}$, a longer process duration leads to lower transmission values in the range of 250 to $400 \mathrm{~nm}$. The lowest values are determined for the sample with $15 \mathrm{~min}$ process duration. Even after dialysis, the transmission
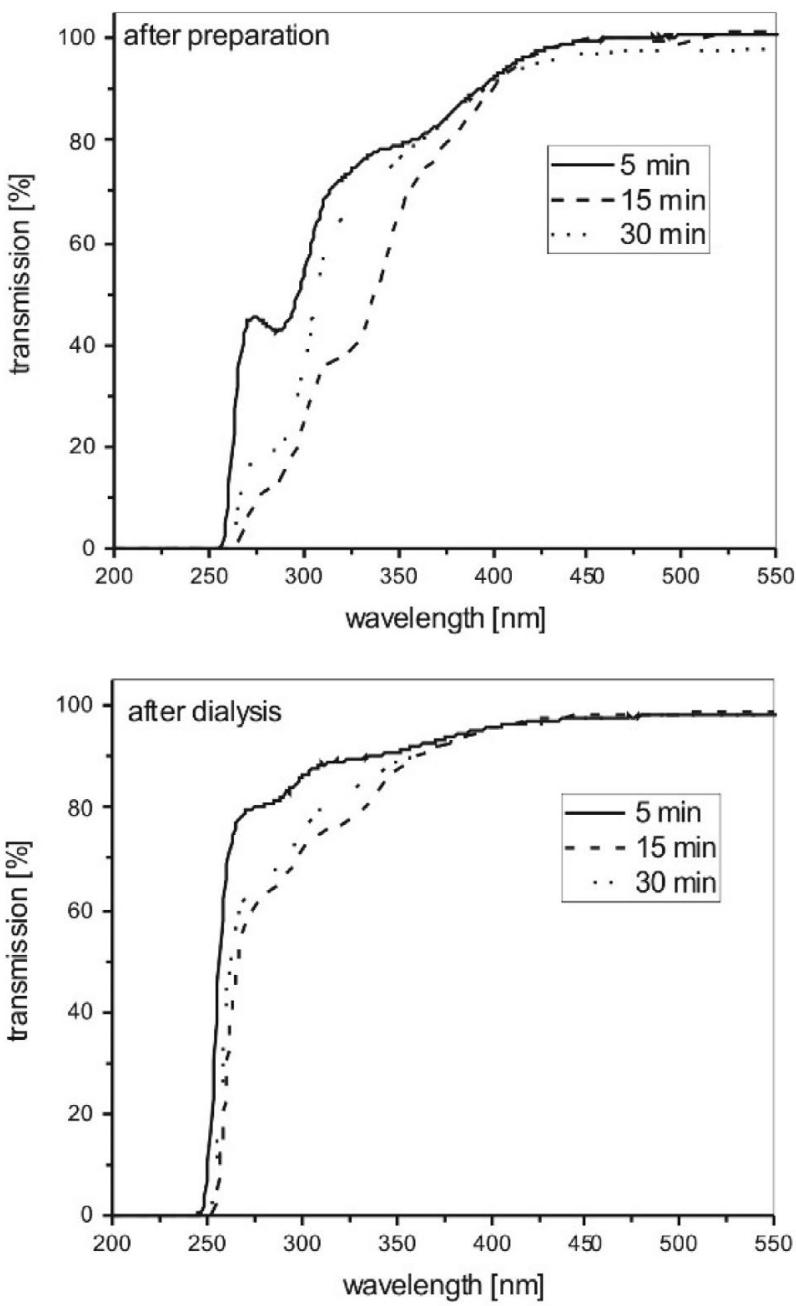

Figure 5. UV/Vis-transmission spectra of the prepared solution recorded directly after preparation (image above) and after treatment by dialysis (image below). Presented are spectra from solutions prepared with different process duration under a process temperature of $140^{\circ} \mathrm{C}$.

values are still low (compare Figures 4 and 5). This observation indicates that during microwave synthesis UV-absorbing particles with diameters larger than $3 \mathrm{~nm}$ are formed.

The fluorescence spectra of the prepared solutions are presented in Figure 6. The activation of fluorescence is done with UV-light of $360 \mathrm{~nm}$. The fluorescence is correlated to the used process temperature for sample preparation. The lowest fluorescence is found for samples prepared at $80^{\circ} \mathrm{C}$ (Figure 6). The strongest fluorescence is reached after preparation at $140^{\circ} \mathrm{C}$. Using a process temperature of $100^{\circ}$ or $120^{\circ} \mathrm{C}$ leads to solutions with similar mean fluorescence values. After cleaning by dialysis, the fluorescence is strongly decreased but for samples prepared at $140{ }^{\circ} \mathrm{C}$ it is still significant (Figure 6). It can be assumed that fluorescent compounds are formed by the used microwave synthesis. These components have different particle sizes higher and lower than $3 \mathrm{~nm}$. The larger 

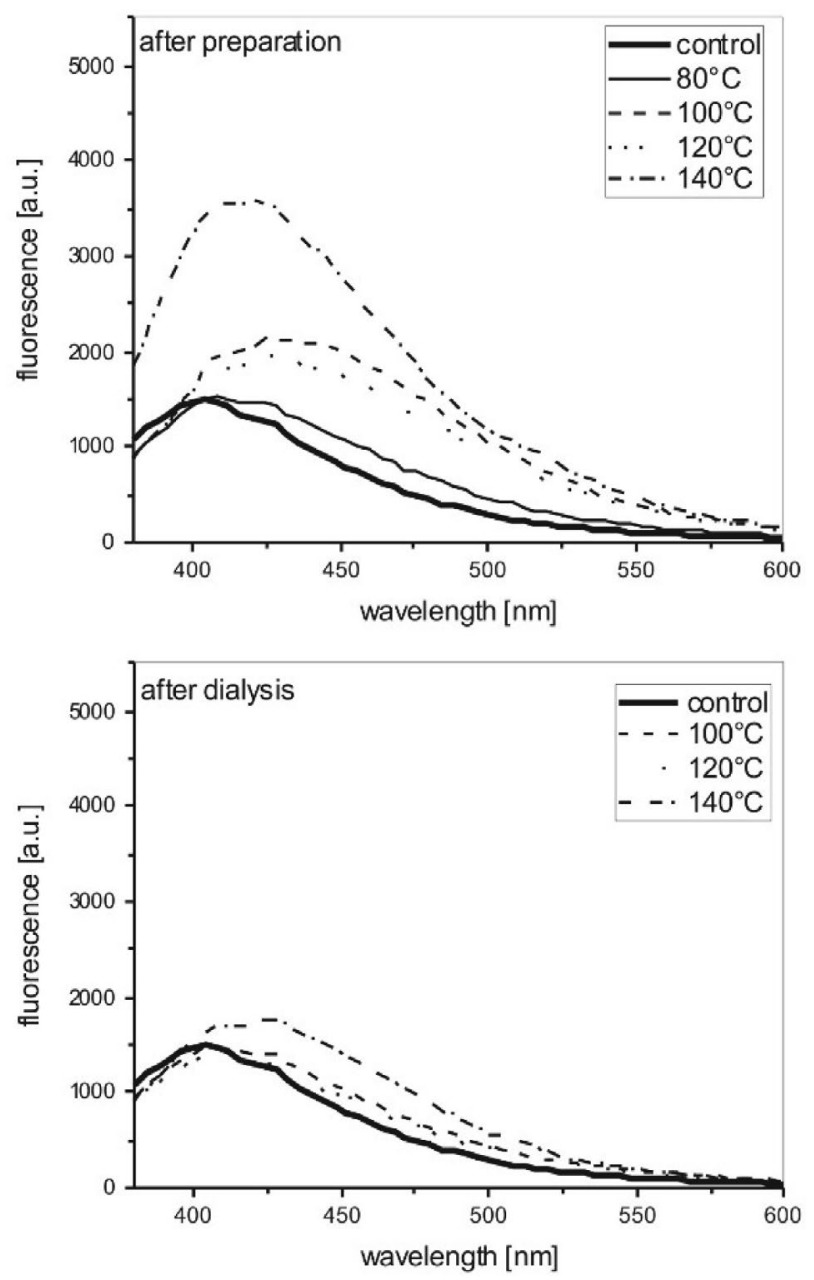

Figure 6. Fluorescence emission spectra of the prepared solutions. For activation, light with $360 \mathrm{~nm}$ is used. Presented are spectra from solutions prepared at different process temperatures with a process duration of 5 minutes.

fluorescence particles are still present in the solution after the dialysis.

The fluorescence emission spectra of samples prepared at $140{ }^{\circ} \mathrm{C}$ and with increasing process duration are compared in Figure 7. It is clearly seen that the process duration has a significant influence on the gained fluorescence. Highest fluorescence values are received for the sample prepared at $140{ }^{\circ} \mathrm{C}$ with 15 minutes process duration in the microwave. For fluorescence activation with light of $360 \mathrm{~nm}$, the maximum fluorescence emission is found to be at $428 \mathrm{~nm}$. After performing the dialysis, the intensity of the fluorescence decreases but is still significant. The strongest fluorescence is gained for the sample prepared at $140{ }^{\circ} \mathrm{C}$ with a process duration of $30 \mathrm{~min}$. For these preparation conditions the fluorescence emission maximum is observed at $436 \mathrm{~nm}$ for an activation with light of $360 \mathrm{~nm}$.

The activation spectra for an emission at $440 \mathrm{~nm}$ are recorded in Figures 8 and 9. For samples prepared at $80^{\circ}$, $100^{\circ}$ or $120^{\circ} \mathrm{C}$, the activation of fluorescence is mainly
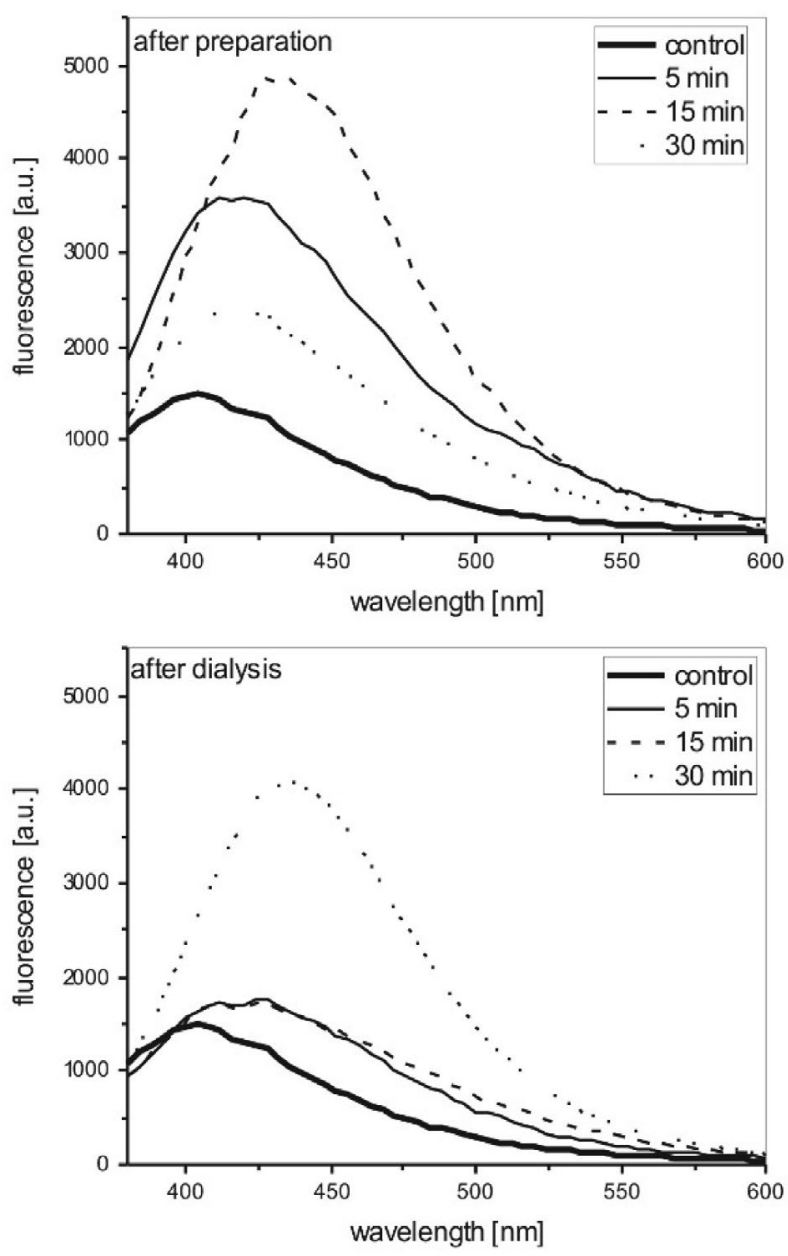

Figure 7. Fluorescence emission spectra of the prepared solutions. For activation light with $360 \mathrm{~nm}$ is used. Presented are spectra from solutions prepared with different process duration under a process temperature of $140^{\circ} \mathrm{C}$.

supported by UV-light in the range of 360 to $380 \mathrm{~nm}$ (Figure 8). In contrast, the activation spectrum for the sample prepared at $140{ }^{\circ} \mathrm{C}$ is totally different. In addition to the activation in the area of $360^{\circ}$ to $380^{\circ} \mathrm{C}$, for this sample the activation spectrum exhibits a strong maximum at 324 $\mathrm{nm}$ (Figure 8). After dialysis, no fluorescence activation around $320 \mathrm{~nm}$ or below is recorded. The fluorescence for that spectral area is obviously related to lower molecular mass compounds or small particles with diameters smaller than $3 \mathrm{~nm}$. However, the fluorescence in the range of 340 to $380 \mathrm{~nm}$ is still present after dialysis, so this fluorescence is probably related to particles with diameters larger than $3 \mathrm{~nm}$.

For many practical applications, as e.g. on textile substrates, a fluorescence activation in the range of 360 to $380 \mathrm{~nm}$ is required, while an activation at lower wavelengths of around $320 \mathrm{~nm}$ is of lower relevance. An optical brightener transfers UV-light into visible blue light and gives the treated textile a whitened appearance. ${ }^{37,38}$ For this application a fluorescence activation in the range of 360 to $380 \mathrm{~nm}$ is important, because the UV-content in 

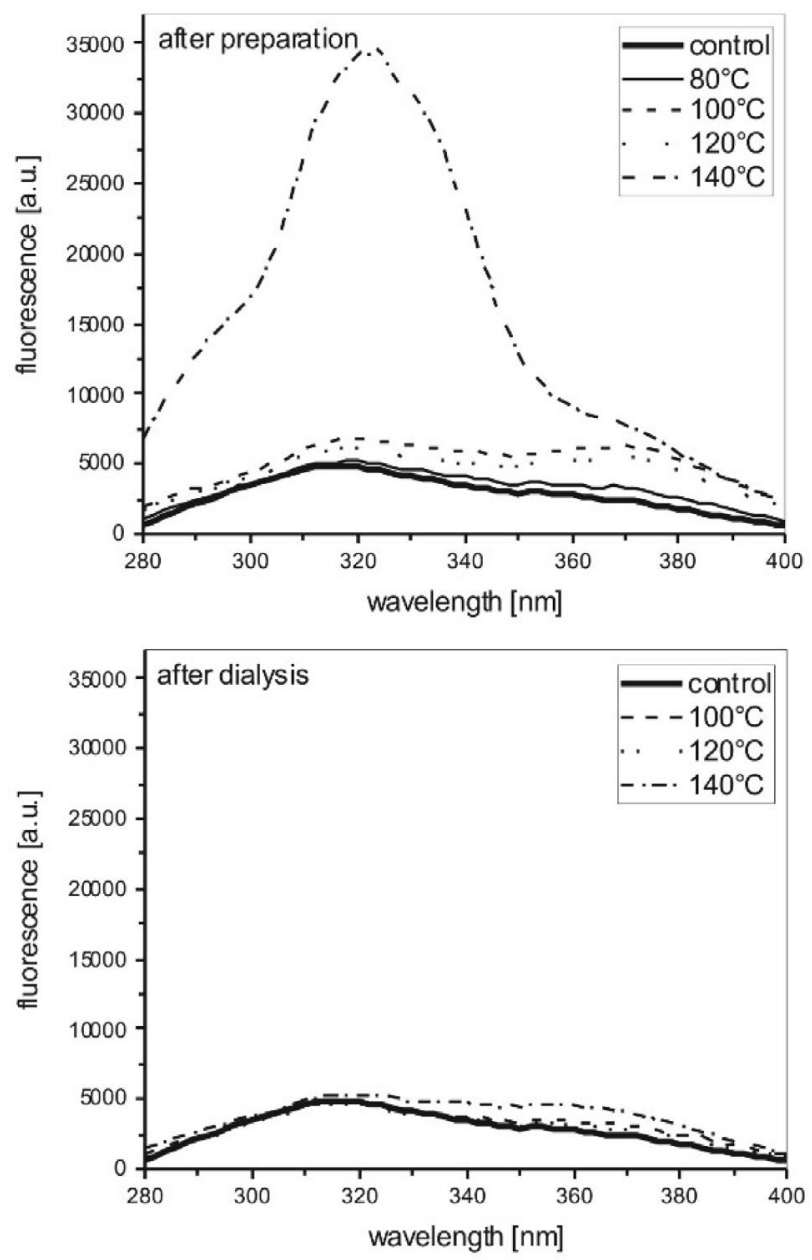

Figure 8. Fluorescence activation spectra of the prepared solutions. The activation is recorded for fluorescence light emitted at $440 \mathrm{~nm}$. Presented are spectra from solutions prepared at different process temperatures with a process duration of $5 \mathrm{~min}$.

sunlight filtered by glass is mainly present in this range and not at lower wavelength of $320 \mathrm{~nm} \cdot{ }^{39,40}$

The fluorescence activation spectra for an emission of $440 \mathrm{~nm}$ of samples prepared at $140^{\circ} \mathrm{C}$ and different process durations are presented in Figure 9. The fluorescence activation is strong over the whole range from 280 to $400 \mathrm{~nm}$. For a process duration of 5 or $30 \mathrm{~min}$ a prominent activation maximum around $320 \mathrm{~nm}$ is recorded. For the intermediate duration of $15 \mathrm{~min}$ a broad activation plateau from 320 to $360 \mathrm{~nm}$ is observed. After dialysis, the activation is decreased, especially for wavelengths smaller than $340 \mathrm{~nm}$. The sample prepared after 30 min exhibits after dialysis a significant fluorescence activation with UV-light around $360 \mathrm{~nm}$.

\section{2. Properties of Prepared Textile Samples}

Cotton samples treated with the solutions prepared at $140{ }^{\circ} \mathrm{C}$ and cleaned by dialysis are presented in Figure 10. Under illumination with UV-A light, these samples exhibit the emission of a blue fluorescence.
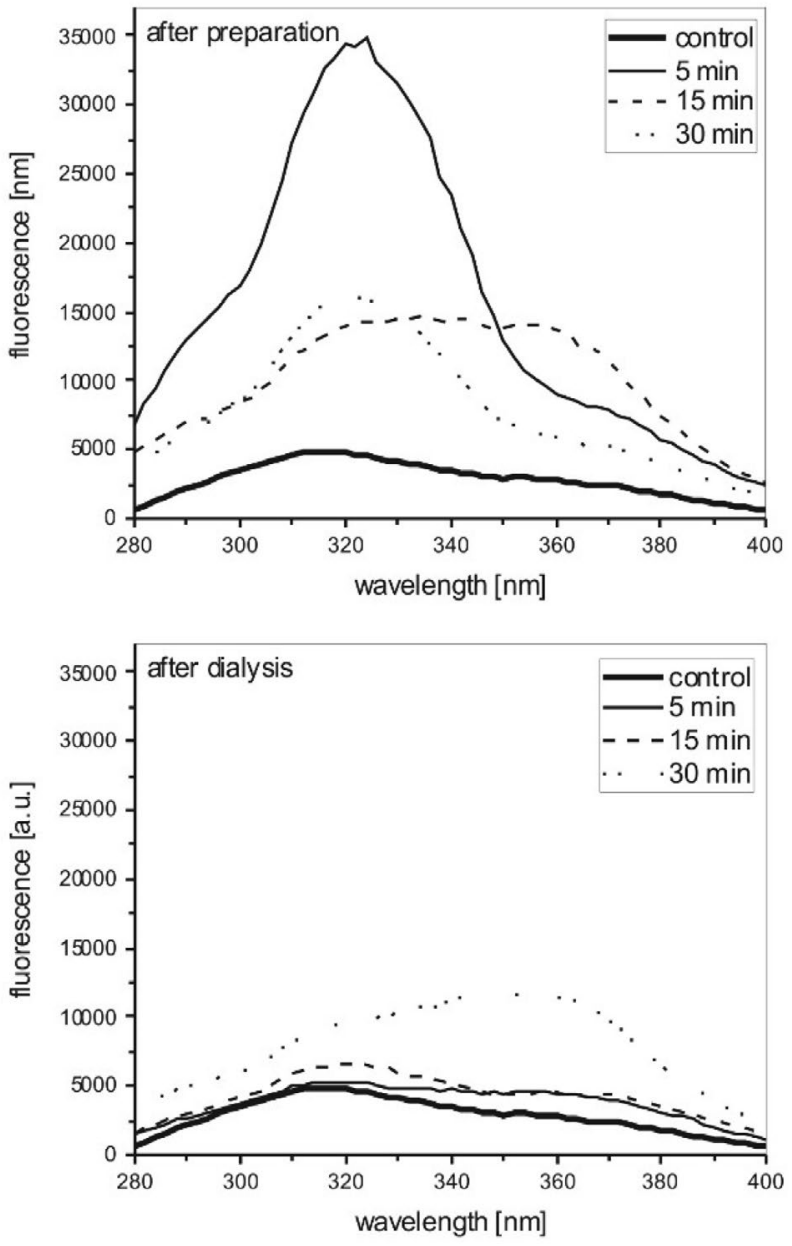

Figure 9. Fluorescence activation spectra of the prepared solutions. The activation is recorded for fluorescence light emitted at $440 \mathrm{~nm}$. Presented are spectra from solutions prepared with different process duration under a process temperature of $140^{\circ} \mathrm{C}$.

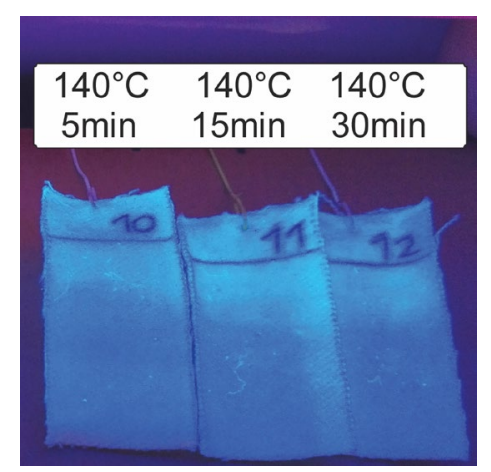

Figure 10. Textile samples treated with the different solutions under illumination with a UV-lamp. The process temperature of $140{ }^{\circ} \mathrm{C}$ and process duration for solution preparation is indicated for each sample. After application of the solution, the textile samples are dried at $120^{\circ} \mathrm{C}$.

The fluorescence activation spectra of the textiles are given in Figure 11. These activation spectra are recorded for fluorescence light emitted at $440 \mathrm{~nm}$. In Figure 11, sam- 

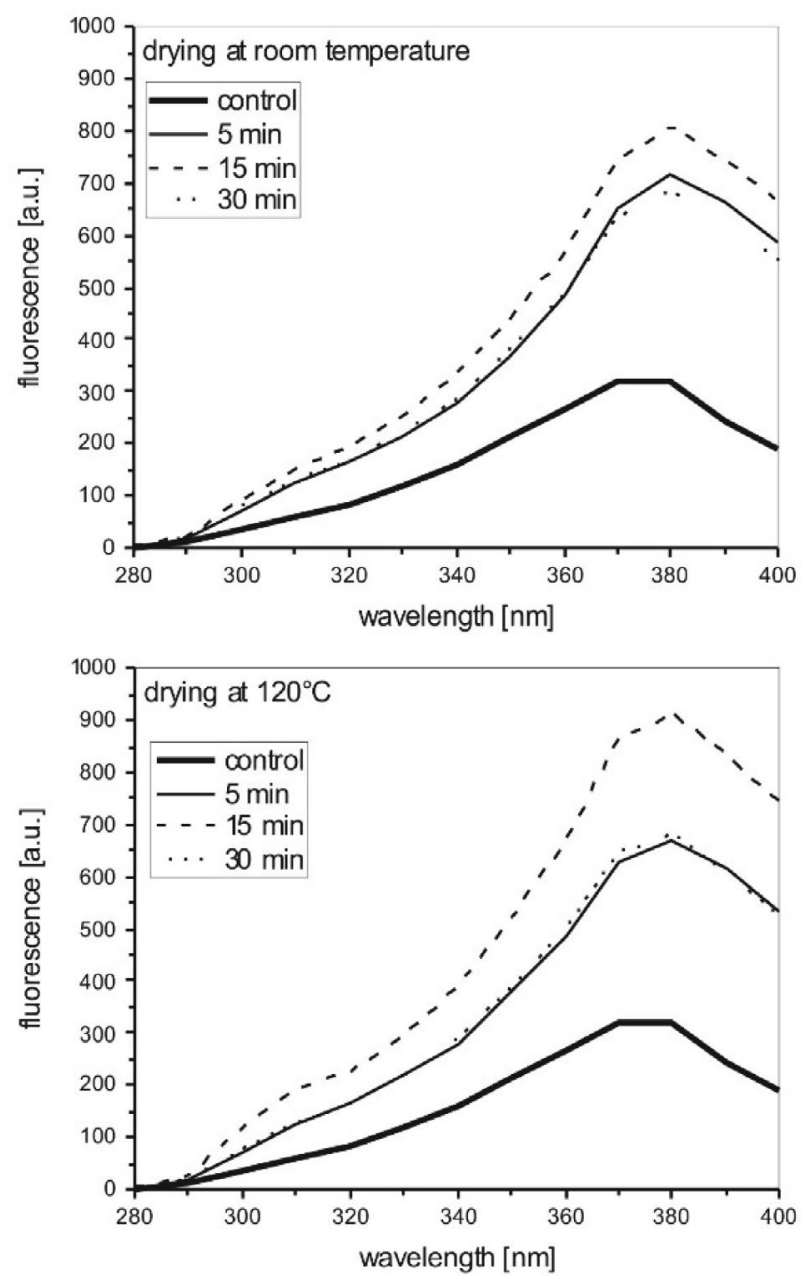

Figure 11. Fluorescence activation spectra of the prepared textiles. The activation is recorded for fluorescence light emitted at $440 \mathrm{~nm}$. Presented are textiles prepared with solutions realized with different process duration under a process temperature of $140{ }^{\circ} \mathrm{C}$. After solution application the textile samples are dried at room temperature or at $120^{\circ} \mathrm{C}$

ples with different process duration for solution preparation and different drying procedures of the treated textiles are compared. All samples exhibit a significant activation maximum for UV-light with $380 \mathrm{~nm}$. A slightly stronger activation is determined for the sample with process duration of $15 \mathrm{~min}$. The drying of textile samples at $120^{\circ} \mathrm{C}$ does not lead to a decrease of the fluorescence, so the fluorescent components are obviously stable under these thermal conditions. As mentioned above, from the point of view of practical applications, both the activation maximum around $380 \mathrm{~nm}$ and the thermal stability are important.

The fluorescence emission spectra of the treated textiles ( $380 \mathrm{~nm}$ activation) are summarized in Figure 12. The maximum of the fluorescence emission is around $450 \mathrm{~nm}$. Samples prepared from solutions with process durations of 5 or 30 min exhibit nearly the same intensity of fluorescence. In comparison with the intermediate process duration of $15 \mathrm{~min}$ a higher fluorescence emission is observed.
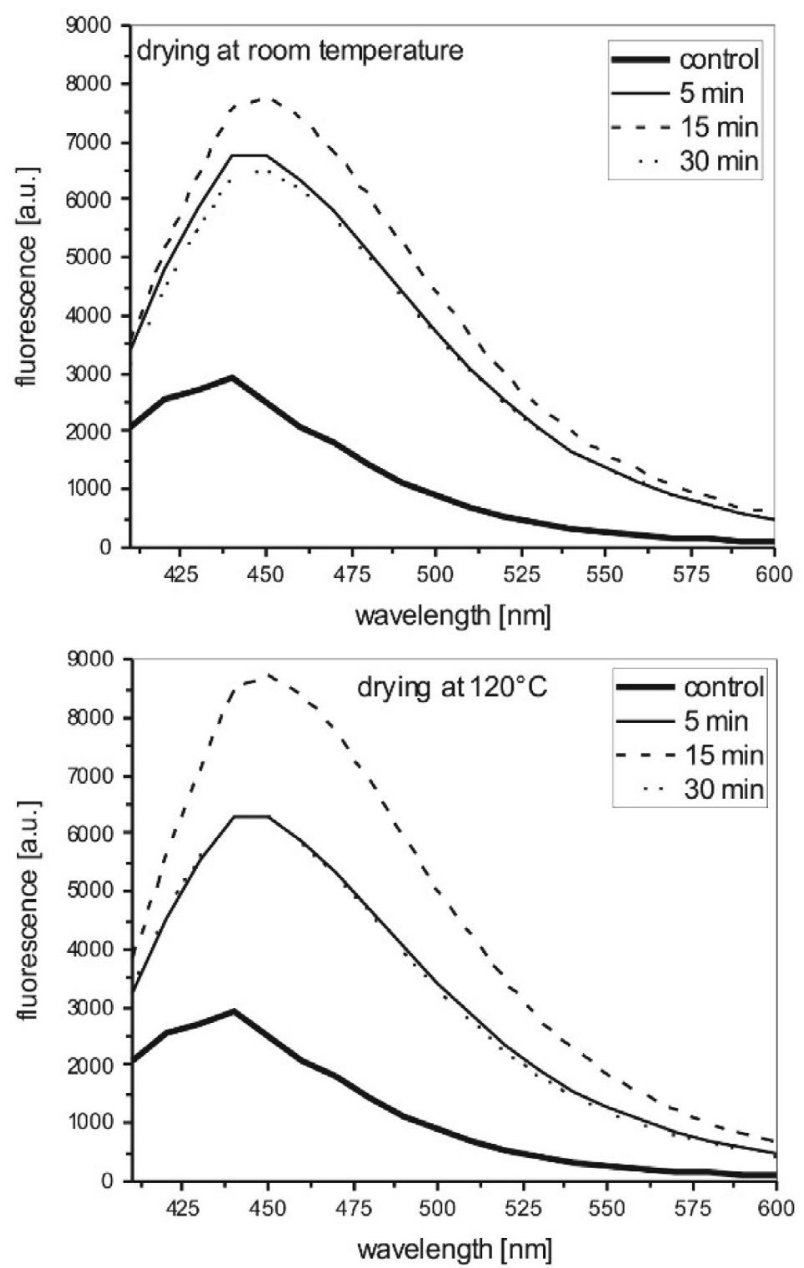

Figure 12. Fluorescence emission spectra of the prepared textiles. For activation light with $380 \mathrm{~nm}$ is used. Presented are textiles prepared with solutions realized with different process duration under a process temperature of $140{ }^{\circ} \mathrm{C}$. After solution application the textile samples are dried at room temperature or at $120^{\circ} \mathrm{C}$.

For both drying procedures of the treated textiles (at room temperature or at $120^{\circ} \mathrm{C}$ ) the same high fluorescence values are determined.

\section{3. Modification of Recipe with Different Amino Acids}

Taking the both amino acids glycine and lysine as precursors, fluorescent solutions can be prepared by the used microwave assisted process using a process temperature of $140{ }^{\circ} \mathrm{C}$ with a duration of 15 minutes (see Figure 13). Under the chosen conditions, different fluorescent coloration results depending on the type of amino acid used as precursor. By using lysine, blue fluorescent coloration results, which is similar to the result gained with the precursor L-arginine (compare Figures 3 and 13). In comparison, the use of glycine leads to a fluorescent coloration that can be described as yellow to white (Figure 13). 


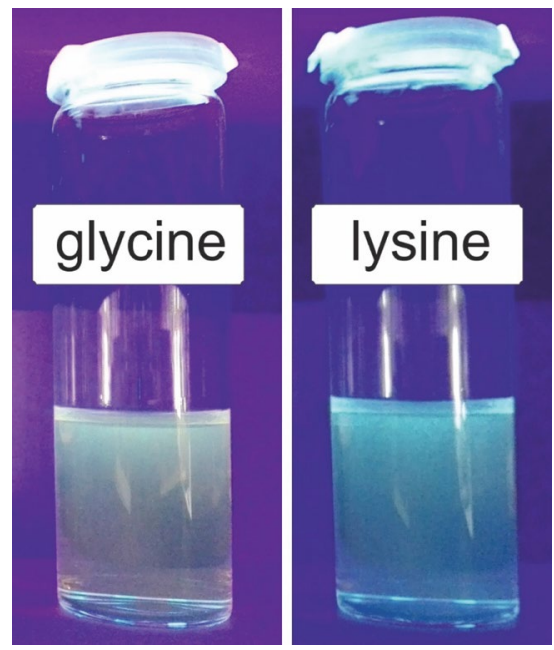

Figure 13. Solutions after preparation with the precursors glycine or lysine under illumination with a UV lamp. The process temperature is $140^{\circ} \mathrm{C}$ and the process duration is 15 minutes.
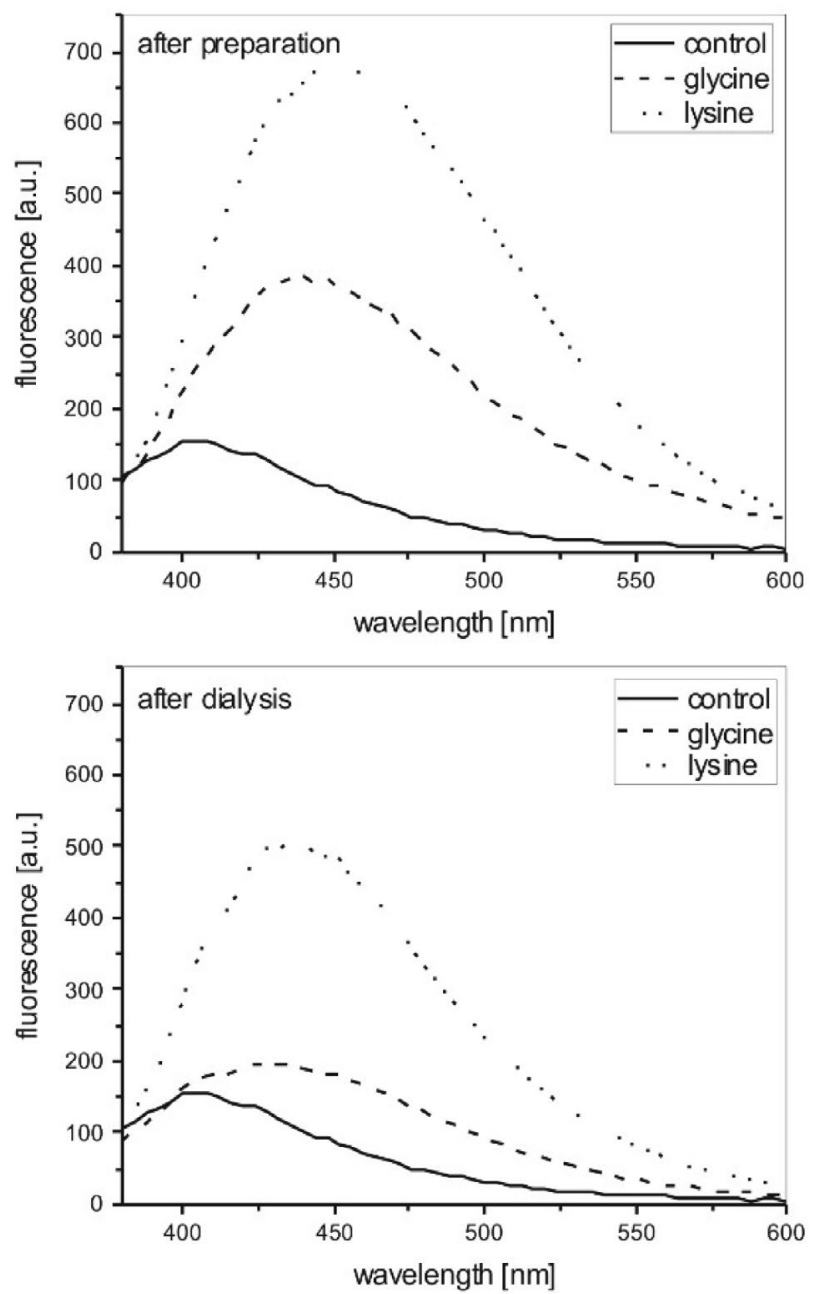

Figure 14. Fluorescence emission spectra of solutions prepared with the amino acids glycine or lysine. For activation, light with 360 $\mathrm{nm}$ is used. Presented are spectra from solutions prepared with a process temperature of $140^{\circ} \mathrm{C}$ and a process duration of 15 minutes.
The fluorescence emission spectra of solutions prepared with the amino acids glycine or lysine are shown in Figure 14. With lysine as precursor a stronger fluorescence can be reached compared to lower values gained with glycine. The maximum of fluorescence for preparations with lysine can be determined at $452 \mathrm{~nm}$ after preparation and at $436 \mathrm{~nm}$ after dialysis of the solutions. This spectroscopic result corresponds well to the observed blue coloration (Figure 13). The preparation with glycine leads to fluorescent maxima at lower wavelength $-440 \mathrm{~nm}$ after preparation and $424 \mathrm{~nm}$ after dialysis of the solutions. Compared to the emission intensity at the fluorescence maximum for solutions from lysine as precursor, the fluorescence decreased stronger at higher wavelength. At $600 \mathrm{~nm}$ only around $9 \%$ of the emission intensity of the fluorescent maximum is determined, for solutions from lysine as precursor. For glycine prepared solutions, at $600 \mathrm{~nm}$ a higher ratio of around $13 \%$ emission intensity of the fluorescent maximum is observed (Figure 14). This more intensive flu-
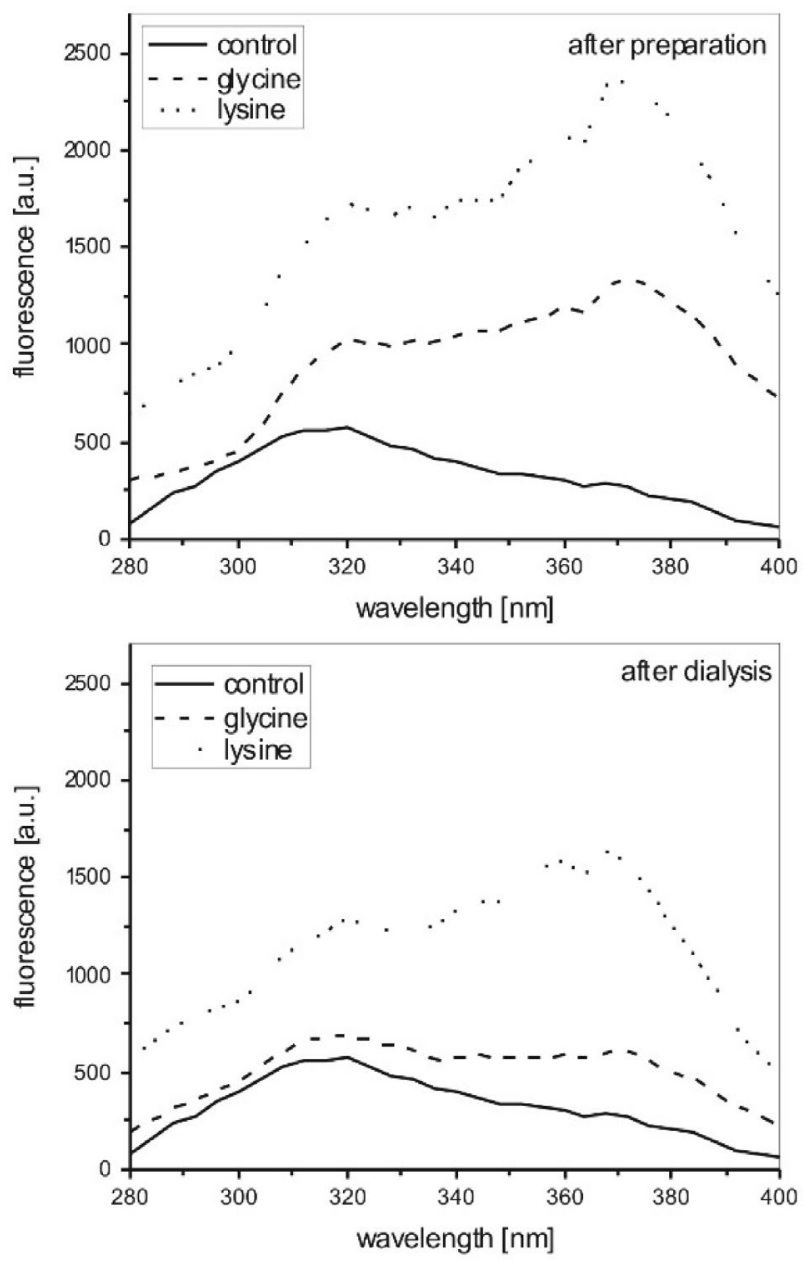

Figure 15. Fluorescence activation spectra of the solutions prepared with the amino acids glycine and lysine. The activation is recorded for fluorescence light emitted at $440 \mathrm{~nm}$. Presented are spectra from solutions prepared with a process temperature of $140{ }^{\circ} \mathrm{C}$ and a process duration of 15 minutes. 
orescence emission at higher wavelength is in relation with the yellow coloration of this solution, as seen in Figure 13.

The fluorescence activation spectra of solutions prepared with the amino acids glycine or lysine are shown in Figure 15. The activation spectra of both solutions exhibit different activation intensity but a similar shape of the spectra with two dominating maxima at $320 \mathrm{~nm}$ and 372 $\mathrm{nm}$. After dialysis, especially the glycine based solution exhibits a strong decrease in fluorescence activation. This decrease could be explained by the formation of fluorescent molecules and particles smaller $3 \mathrm{~nm}$, which are removed by dialysis from the prepared solution.

\section{Conclusions}

A microwave process driven under solvothermal conditions can be used for the preparation of fluorescent solutions based on the thermal conversion of simple amino acids, which are arginine, lysine and glycine. The effectivity of conversion is determined by the process temperature used in the solvothermal process. Best results are gained for a process temperature of $140{ }^{\circ} \mathrm{C}$. The fluorescent components can be distinguished into components with different particle sizes smaller and larger than $3 \mathrm{~nm}$ in diameter. The solutions are suitable for application onto textiles, e.g. as optical brighteners or as fluorescence marker. The fluorescence activation is driven mainly with UV-light in the range of 360 to $380 \mathrm{~nm}$ which fits to the UV-light present in sunlight. Also the thermal stability necessary for drying and fixation processes is given. A first proof-ofconcept is provided that by microwave synthesis the conversion of amino acids into fluorescent particles is possible. These particles present in homogeneous, transparent and aqueous solutions can be used as finishing agent for textiles.

\section{Acknowledgements}

All product and company names mentioned in this chapter may be trademarks of their respective owners, also without labeling. For many helpful discussions and technical help in the lab many thanks have to be acknowledged to Dr. Thomas Grethe from Niederrhein University of Applied Sciences.

\section{References}

1. P. K. Jain, X. Huang, I. H. El-Sayed, M. A. El-Sayed, Plasmonics 2007, 2, 107-118. DOI:10.1007/s11468-007-9031-1

2. F. E. Kruis, H. Fissan, A. Peled, J. Aerosol Sci. 1998, 29, 511535. DOI:10.1016/S0021-8502(97)10032-5

3. S. Farhadi, B. Ajerloo, A. Mohammadi, Acta Chim. Slov. 2017, 64, 129-143. DOI:10.17344/acsi.2016.2956
4. E. Soleimani, N. Zamani, Acta Chim. Slov. 2017, 64, 644-653. DOI:10.17344/acsi.2017.3459

5. S. Abdolmohammadi, M. Afsharpour, Z. Naturforsch. 2015, 70b, 171-176.

6. B. Mahltig, H. Haufe, K. Muschter, A. Fischer, Y. H. Kim, E. Gutmann, M. Reibold, D. C. Meyer, T. Textor, C. W. Kim, Y. S. Kang, Acta Chim. Slov. 2010, 57, 451-457.

7. B. Mahltig, M. Reibold, E. Gutmann, T. Textor, J. Gutmann, H. Haufe, H. Haase, Z. Naturforsch. 2011, 66b, 905-916.

8. D. Salz, B. Mahltig, A. Baalmann, M. Wark, N. Jaeger, Phys. Chem. Chem. Phys. 2000, 2, 3105-3110.

DOI: $10.1039 / \mathrm{b} 002327 \mathrm{~m}$

9. X. Xu, R. Ray, Y. Gu, H. J. Ploehn, L. Gearheart, K. Raker, W. A. Scrivens, J. Am. Chem. Soc. 2004, 126, 12736-12737. DOI: $10.1021 / \mathrm{ja} 040082 \mathrm{~h}$

10. Y. Wang, A. Hu, J. Mater. Chem. C 2014, 2, 6921-6939. DOI:10.1039/C4TC00988F

11. X. T. Zheng, A. Ananthanarayanan, K. Q. Luo, P. Chen, Small 2015, 11, 1620-1635. DOI:10.1002/smll.201402648

12. J. Wang, C. F. Wang, S. Chen, Angew. Chem. Int. Ed. 2012, 51, 9297-9301. DOI:10.1002/anie.201204381

13. S. Y. Lim, W. Shen, Z. Gao, Chem. Soc. Rev. 2015, 44, 362-381. DOI:10.1039/C4CS00269E

14. P. Innocenzi, L. Malfatti, D. Carboni, Nanoscale 2015, 7, 12759-12772. DOI:10.1039/C5NR03773E

15. K. Suzuki, L. Malfatti, D. Carboni, D. Loche, M. Casula, A. Moretto, M. Maggini, M. Takahashi, P. Innocenzi, J. Phys. Chem. C 2015, 119, 2837-2843. DOI:10.1021/jp510661d

16. X. Zhai, P. Zhang, C. Liu, T. Bai, W. Li, L. Dai, W. Liu., Chem. Commun. 2012, 48, 7955-7957. DOI:10.1021/jp510661d

17. J. Baker, 50 Schlüsselideen Quantenphysik, Springer Spektrum Verlag, Berlin, 2015. DOI:10.1007/978-3-662-45033-8

18. K. A. S. Fernando, S. Sahu, Y. Liu, W. K. Lewis, E. A. Guliants, A. Jafariyan, P. Wang, C. E. Bunker, Y. P. Sun, ACS Appl. Mater. Interfaces 2015, 7, 8363-8376.

DOI:10.1021/acsami.5b00448

19. P. Wang, R. B. Zhong, M. Yuan, P. Gong, X. Zhao, F. Zhang, Nucl. Sci. Techn. 2016, 27, 35. DOI:10.1007/s41365-016-0038-1

20. M. Gupta, S. Paul, R. Gupta, Acta Chim. Slov. 2009, 56, 749764.

21. C. O. Kappe, Ange. Chem. Int. Ed. 2004, 43, 6250-6284.

22. N. Kuhnert, Ange. Chem. Int. Ed. 2002, 41, 1863-1866.

23. M. Larhed, A. Hallberg, Drug Discovery Today 2001, 6, 406416. DOI:10.1016/S1359-6446(01)01735-4

24. P. Lidström, J. Tierney, B. Wathey, J. Westman, Tetrahedron 2001, 57, 9225-9283. DOI:10.1016/S0040-4020(01)00906-1

25. R. M. Shaker, M. A. Elrady, Z. Naturforsch. 2008, 63b, 14311437.

26. D. Li, S. Komarneni, Z. Naturforsch. 2006, 61b, 1566-1572.

27. S. Komarneni, Y. D. Noh, J. Y. Kim, S. H. Kim, H. Katsuki, Z. Naturforsch. 2010, 65b, 1033-1037.

28. B. Mahltig, E. Gutmann, M. Reibold, D. C. Meyer, H. Böttcher, J. Sol-Gel Sci. Technol. 2009, 51, 204-214.

DOI:10.1007/s10971-009-1972-8

29. B. Mahltig, H. Miao, J. Coat. Technol. Res. 2017, 14, 721-733. DOI:10.1007/s11998-016-9891-4 
30. S. Dinc, M. Kara, M. D. Kars, F. Aykül, H. Cicekci, M. Akkus, Appl. Phys. A 2017, 123, 572-579.

DOI:10.1007/s00339-017-1184-y

31. M. L. Bhaisare, A. Talib, M. S. Khan, S. Pandey, H. F. Wu, Microchim. Acta 2015, 182, 2173-2181.

DOI:10.1007/s00604-015-1541-5

32. X. Wang, K. Qu, B. Xu, J. Ren, X. Qu, J. Mater. Chem. 2011, 21, 2445-2450. DOI:10.1039/c0jm02963g

33. D. Mazzier, M. Favaro, S. Agnoli, S. Silvestrini, G. Granozzi, M. Maggini, A. Moretto, Chem. Commun. 2014, 50, 65926595. DOI:10.1039/C4CC02496F

34. D. Mosconi, D. Mazzier, S. Silvestrini, A. Privitera, C. Marega,
L. Franco, A. Moretto, ACS Nano 2015, 9, 4156-4164.

DOI:10.1021/acsnano.5b00319

35. U. Sengutta, H. P. Meier, GIT Labor-Fachzeitschrift 2002, 46, 1038-1043.

36. H. Ritter, J. Theis, GIT Labor-Fachzeitschrift 2011, 55, 170-173.

37. R. A. Mustalish, Studies in Conservation 2000, 45, 133-136.

DOI:10.1179/sic.2000.45.Supplement-1.133

38. I. H. Leaver, B. Milligan, Dyes and Pigments 1984, 5, 109-144. DOI:10.1016/0143-7208(84)80008-X

39. P. Brennan, C. Fedor, G. Pausch, Paint and Resin 1988, 58, 17.

40. C. Tuchinda, S. Srivannaboon, H. W. Lim, J. Am. Acad. Dermatol. 2006, 54, 845-854. DOI:10.1016/j.jaad.2005.11.1082

\section{Povzetek}

Sinteza z uporabo mikrovalov je že dobro uveljavljena metoda v organski in anorganski sintezni kemiji. Prav tako se uporablja na področju materialov za pripravo novih ogljikovih nanodelcev, ki izražajo fluorescenčne lastnosti. V tej raziskavi je predstavljena $\mathrm{z}$ mikrovalovi spodbujena solvatotermna sinteza, ki je bila uporabljena za pretvorbo amino kislin in 1,2-diaminoetana $\mathrm{v}$ različne fluorescenčne raztopine. $\mathrm{V}$ študiji so kot modelne amino kisline uporabili arginin, lizin in glicin, v temperaturnem območju reakcije od $80^{\circ}$ do $140{ }^{\circ} \mathrm{C}$ in pri tlaku 4.5 bar. Reakcije so potekale od 5 do 30 minut. Fluorescenčni efekt se povečuje s višanjem temperature. Pripravljene vodne fluorescenčne raztopine lahko uporabimo kot medij za indukcijo fluorescence na tekstilnih substratih. Študija je prvi primer potrditve koncepta preproste, $\mathrm{z}$ mikrovalovi asistirane solvatotermne sinteze fluorescenčnih raztopin, ki je uporaben za modifikacijo različnih substratov. 